\title{
The NREL Outdoor Accelerated- weathering Tracking System and Photovoltaic Module Exposure Results
}

Thomas S. Basso

National Renewable Energy Laboratory

Presented at the National Center for

Photovoltaics Program Review Meeting

Denver, Colorado

September 8-11, 1998

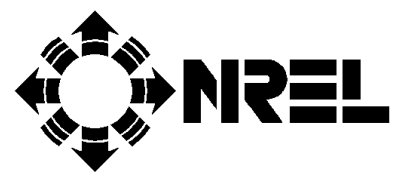

National Renewable Energy Laboratory 1617 Cole Boulevard Golden, Colorado 80401-3393

A national laboratory of the U.S. Department of Energy Managed by Midwest Research Institute for the U.S. Department of Energy under contract No. DE-AC36-83CH10093

Work performed under task number PV806101

October 1998 


\begin{abstract}
NOTICE
This report was prepared as an account of work sponsored by an agency of the United States government. Neither the United States government nor any agency thereof, nor any of their employees, makes any warranty, express or implied, or assumes any legal liability or responsibility for the accuracy, completeness, or usefulness of any information, apparatus, product, or process disclosed, or represents that its use would not infringe privately owned rights. Reference herein to any specific commercial product, process, or service by trade name, trademark, manufacturer, or otherwise does not necessarily constitute or imply its endorsement, recommendation, or favoring by the United States government or any agency thereof. The views and opinions of authors expressed herein do not necessarily state or reflect those of the United States government or any agency thereof.
\end{abstract}

Available to DOE and DOE contractors from:

Office of Scientific and Technical Information (OSTI)

P.O. Box 62

Oak Ridge, TN 37831

Prices available by calling 423-576-8401

Available to the public from:

National Technical Information Service (NTIS)

U.S. Department of Commerce

5285 Port Royal Road

Springfield, VA 22161

703-605-6000 or 800-553-6847

or

DOE Information Bridge

http://www.doe.gov/bridge/home.html 


\title{
The NREL Outdoor Accelerated-weathering Tracking System and Photovoltaic Module Exposure Results
}

\author{
Thomas S. Basso \\ National Renewable Energy Laboratory (NREL) \\ 1617 Cole Blvd., Golden, CO, 80401-3393
}

\begin{abstract}
This paper describes the Outdoor Accelerated-weathering Tracking System (OATS) and interim results for the first OATS study on photovoltaic (PV) modules. With two test planes measuring $1.52 \times 1.83$ $\mathrm{m}$, OATS provides a unique solar-concentrating exposure capability. Test sample temperatures are moderated by air blowers. Water spray capability exists for wetting samples. The OATS two-axis tracker points to the sun using software calculations. Non-imaging aluminum reflectors give a nominal clear-sky optical concentration ratio of three. Field-qualification measurements in the test plane under reflector conditions showed its relative irradiance non-uniformity was " $15 \%$ for a clear-sky summer day with " 75 $\mathrm{mm}$ as the smallest distance for that non-uniformity. Exposure studies began in November 1997 on seven pairs of commercially available ribbon silicon, crystalline silicon and amorphous silicon PV modules kept at constant resistive load. The modules were periodically removed from OATS for visual inspection and solar simulator performance measurements. There were no module failures. This PV module study is ongoing and later results will be compared to other testing techniques. Through July 1998, the modules under reflector conditions received $392 \mathrm{MJ} / \mathrm{m}^{2}$ of total ultraviolet (TUV) exposure. That was 2.07 times the TUV exposure compared to a south-facing fixed array tilted $40^{\circ}$ up from horizontal at NREL. Similarly, the modules in the test plane under the covered reflectors received 1.04 times the fixed array TUV exposure. For the test plane under the covered reflectors there was a loss of $13 \%$ TUV exposure attributed to the reflectors blocking some of the diffuse-sky UV light. Also through July 1998, the OATS sunlight availability measured $95 \%$ compared to the cumulative global normal exposure at the NREL Solar Radiation Research Laboratory (SRRL). The OATS sunlight availability losses included downtime when the PV modules were removed, and when there were OATS tracking problems, maintenance, and repair. For December 1997 through July 1998, the SRRL cumulative exposure was 99\% compared to the respective monthly averages from years 1961 through 1990 at Boulder, Colorado.
\end{abstract}

\section{INTRODUCTION}

The Outdoor Accelerated-weathering Tracking System (OATS) was procured by NREL through a competitive proposal process. The OATS is a unique sunlight-concentrating design based largely on Carizzo Solar Plains tracker technology. The OATS system is meant to provide accelerated stress testing of photovoltaic (PV) modules. The testing purpose is to assess the ability of a module to withstand ultraviolet (UV) radiation and outdoor exposure, focusing on degradation of module encapsulants and other polymer 
components, the PV device structures, and general module components. The first PV modules were deployed 11/22/97. This paper describes OATS and provides interim results because there are not yet test failures.

\section{SYSTEM DESCRIPTION}

The OATS is a two-axis solar tracking weatherometer having two test planes $1.52 \mathrm{~m}$ (5 $\mathrm{ft})$ by $1.83 \mathrm{~m}(6 \mathrm{ft})$ that can accomodate $206 \mathrm{~kg}(500 \mathrm{lbs})$ each. The test planes have air blowers for ambient air cooling of samples and water spray nozzles for wetting samples. A manually programmable timer controls the air blowers and nozzles. The solar tracking is by time and relative position encoders on azimuth and elevation electric motors. Software calculates the sun position and signals the control electronics to step the motors. Because tracking is not by open feedback from monitoring sunlight, clouds do not affect the pointing and off-axis tracking may be prescribed. The OATS system automatically stows when a wind overspeed condition is sensed.

Solar concentration is by four flat rectangular aluminum reflector panels giving nominal one- two- or three-times direct-beam concentration by covering opposing pairs of reflectors. The aluminum reflector material total solar-weighted specular reflectance measured $88 \%$. The reflectance is $83 \%$ to $92 \%$ in the UV range for wavelengths $<400$ $\mathrm{nm}, 79 \%$ to $93 \%$ in the 400 -to- $750 \mathrm{~nm}$ range, and is primarily in the mid- $90 \%$ range beyond that out to $2400 \mathrm{~nm}$. Field-qualification measurements in the test plane under reflector conditions using a 50-by-100 mm crystal silicon device showed the OATS test plane relative irradiance non-uniformity was " $15 \%$ for a clear-sky summer day. And using an 8-mm-diameter crystal silicon device, " $75 \mathrm{~mm}$ was found to be the smallest distance for the " $15 \%$ non-uniformity.

The computer-based data acquisition system (DAS) for OATS monitors irradiance, environmental, and test sample parameters. The DAS was designed at NREL using commercially available components. The design allows a wide choice of user-specified transducers. The DAS works under user-written software for in-situ, continuous or conditional data sampling. The DAS hardware is composed of a data logger, two multiplexers, a controller switching 12 three-pole relays, and a coaxial-cable interface to a personal computer in the NREL Outdoor Test Facility (OTF) $40 \mathrm{~m}(125 \mathrm{ft}$ ) away from OATS.

The DAS is programmed to take data measurements every 5 seconds with averages recorded either at 5-m or 15-m intervals. Sample monitoring has 16 thermocouple and 32 differential voltage channels. Those data are averaged over $15-\mathrm{m}$ intervals during sunshine. Three sets of environmental and irradiance data are reported over 5-m and 15-m 
intervals during sunshine, and at 15-m intervals otherwise. Daily cumulative irradiance values are also recorded. Irradiance measurements taken outside the test planes are the total irradiance-tracking (Kipp \& Zonen pyranometer), total ultraviolet (TUV) irradiancetracking, (Eppley Lab TUVR pyranometer with passband limits at 295 to $385 \mathrm{~nm}$ ), normal incidence irradiance-tracking (Eppley Lab pyrheliometer) and, total irradiance-tracking (using a crystal silicon solar cell device called an ESTI sensor). The ESTI sensor includes a temperature sensor to allow temperature correction to its irradiance measurement. The environmental and irradiance measurements in each test plane are the total irradiance, total ultraviolet irradiance, ambient temperature, relative humidity and surface wetness.

\section{EXPERIMENT PLAN}

Test protocol for OATS was based on existing standards $(1,2)$. It was decided not to use water spray cycles until baseline experience is established. This first study will ultimately compare OATS results at solar-concentrating conditions and at non-concentrating conditions to other exposure testing techniques-to sunlight exposure on outdoor fixed racks and to lamp exposure in environmental chambers.

Seven pairs of commercially available ribbon silicon, crystalline silicon, and amorphous silicon (a-Si) PV modules (Table 1) were procured and one of each was deployed in the two OATS test planes. One test plane had its reflectors covered so the irradiance is nominally equal to that seen by a two-axis tracker. Each PV module was put at a resistive load calculated to provide approximate one-sun maximum power-point operation. In-situ monitoring is back of module temperature by a copper constantan thermocouple and load current to a shunt resistor. Load voltage may also be monitored. Once a day, module short-circuit current and open-circuit voltage are measured when OATS total irradiancetracking is near $1000 \mathrm{~W} / \mathrm{m}^{2}$. The OATS air blowers were planned to be used to keep the module temperature no greater than $15 \mathrm{C}$ above what is estimated to be the maximum normal operating cell temperature $(60-65 \mathrm{C})$ for modules at one-sun conditions.

TABLE 1. OATS Test Photovoltaic Module Descriptions

\begin{tabular}{|c|c|c|}
\hline Manufacturer & Module Models & Technology \\
\hline Applied Power Corp. & APC50 & ribbon silicon \\
\hline Siemens Solar Industries & M10 \& Pro 1JF & crystalline silicon \\
\hline Solarex Corp. & MSX10 \& MSX20 & crystalline silicon \\
\hline United Solar Systems Corp. & UniSolar 1206 \& 1212 & $\begin{array}{l}\text { Dual-junction } \\
\text { amorphous silicon }\end{array}$ \\
\hline
\end{tabular}


This OATS exposure study was planned to be done in intervals up to $2000 \mathrm{MJ} / \mathrm{m}^{2} \mathrm{TUV}$ exposure or until failure defined as module power having decreased to $25 \%$ of its initial value. The TUV test dose exposure is defined as the UV irradiance integrated below 400

$\mathrm{nm}$. The first TUV exposure interval was planned at $54 \mathrm{MJ} / \mathrm{m}^{2}$. Subsequent TUV intervals should be every $100 \mathrm{MJ} / \mathrm{m}^{2}$ or so, until failure. At the intervals the PV modules are removed from OATS for visual inspection and solar simulator performance measurements. When modules pass the rated power criteria they are returned to OATS for continued exposure testing; otherwise they undergo failure analysis.

\section{RESULTS}

There have been no PV module failures. Interim results and comments follow. The air blowers have been used during the day starting in March 1998 and ongoing, for both test planes. The reported TUV levels include a 1.26 multiplier applied to the measured data.

That is because the TUV test dose was defined as integrated below $400 \mathrm{~nm}$, and because the TUVR instrument spectral response ends at $385 \mathrm{~nm}$. Measurements at SRRL were used to establish the TUVR multiplier to account for the 385-400-nm range (3).

Modules were periodically removed from OATS and visual inspection and solar simulator current-voltage (I-V) measurements were made. Visual inspections showed some minor anomalies, however no modules exhibited any serious defects. Modules \#1.2 to \#7 were under reflector conditions, and modules \#9.2 to \#15 were in the test plane with the reflectors covered.

The I-V performance data were reviewed and compared to the baseline measured in March 1997 (Table 2). So far, only the amorphous silicon modules showed any substantial change and that is attributed to the Staebler-Wronski effect. Some modules also had dark I-V measurements made. The dark I-V provides estimates for the PV module series and shunt resistance values, and for the equivalent series resistance value.

By considering the changes in those resistance values along with the changes in the shape of the light I-V curves, and along with visual inspection findings, it is possible to provide hypotheses for module performance losses. For example, a loss in short-circuit current without significant change in I-V slopes or resistances might lead to hypothesizing the loss is due to darkening of the encapsulant or superstrate.

The OATS irradiance exposure levels for December 1997 through July 1998 were compared to some benchmarks. The PV modules under reflector conditions received 392 $\mathrm{MJ} / \mathrm{m}^{2}$ of TUV exposure, that being 2.07 times the value on a south-facing fixed array 
TABLE 2. Photovoltaic Module ${ }^{(\mathrm{a})}$ Relative Power After OATS Exposure ${ }^{(\mathrm{b})}$

\begin{tabular}{lrrrrrr}
\hline \multicolumn{5}{l}{ Module Model - \# } & \multicolumn{5}{c}{ Relative Power (\% @ ( standard reporting conditions) } \\
\hline APC50 & $\# 1.2$ & 100 & 96.4 & 95.5 & ---- & ----- \\
APC50 & $\# 9.2$ & 100 & 97.7 & 96.7 & 96.6 & ----- \\
M10 & $\# 2$ & 98.2 & 96.3 & 97.6 & 98.0 & 95.8 \\
M10 & $\# 10$ & 98.2 & 98.3 & 98.9 & 97.5 & ----- \\
Pro1JF & $\# 3$ & 97.2 & 95.9 & 96.2 & 97.0 & 95.7 \\
Pro1JF & $\# 11$ & 97.3 & 96.1 & 94.9 & 94.8 & ----- \\
MSX10 & $\# 4$ & 99.2 & 98.2 & 98.5 & 98.7 & 97.6 \\
MSX 10 & $\# 12$ & 98.5 & 97.7 & 97.2 & 97.1 & ----- \\
MSX20 & $\# 5$ & 99.2 & 97.3 & 98.3 & 98.8 & 97.1 \\
MSX20 & $\# 13$ & 98.7 & 98.2 & 98.1 & 99.8 & ----- \\
1206 & $\# 6$ & 85.6 & 77.8 & 71.7 & 71.0 & 72.8 \\
1206 & $\# 14$ & 84.3 & 67.1 & 64.7 & 65.7 & \\
1212 & $\# 7$ & 86.1 & 80.0 & 74.2 & 74.6 & 74.3 \\
1212 & $\# 15$ & 89.2 & 71.4 & 68.2 & 68.9 & ----- \\
\hline
\end{tabular}

(a) Modules \#1.2 - \#7 @ OATS reflector conditions. Module power \% is relative to 3/97 measurement except \#1.2 and \#9.2 relative to 11/97 measurement since they weren't measured 3/97. All modules were exposed (1-sun outdoors) about 30 days during 3/97 to 11/97.

(b) TUV Exposure levels MJ/m2 (date) for modules \#1.2 and \#2 - \#7 and \#9.2 - \#15 follow.

$\begin{array}{llllll}\# 1.2 & 0(3 / 98) & 95(5 / 98) & 228(7 / 98) & ---- & ---- \\ \# 2 \text { - \#7 } & 0(11 / 97) & 54(1 / 98) & 165(3 / 98) & 260(5 / 98) & 392(7 / 98) \\ \# 9.2 \text { - \#15 } & 0(11 / 97) & 54(2 / 98) & 158(5 / 98) & 240(8 / 98) & ----\end{array}$

tilted $40^{\circ}$ up from horizontal at NREL (4). Similarly, the modules in the test plane under the covered reflectors received $197 \mathrm{MJ} / \mathrm{m}^{2}$, that being 1.04 times the fixed array value. That OATS test plane experienced 13\% TUV loss compared to the OATS value measured

outside the test planes. The loss is attributed to the reflectors blocking some of the diffuse-sky UV light. Overall, the OATS sunlight availability was $95 \%$ compared to the cumulative global normal exposure at SRRL (5). The OATS availability losses included time the modules were removed from exposure and downtime for OATS problems, maintenance, and service for upgrading the tracker control electronics. The SRRL cumulative average exposure was $99 \%$ compared to the respective monthly averages for years 1961 through 1990 at Boulder, Colorado (6). 
This initial PV module study will continue. The OATS test protocol is new and will be adjusted as more experience is gained. In-situ data will be more closely reviewed. Hardware upgrade modifications are planned for the sample monitoring, especially for the back of module temperature. And, the OATS results will be compared to other exposure methods when failures or substantial visual anomalies are noted.

\section{ACKNOWLEDGMENTS}

I wish to acknowledge the following colleagues at NREL for their support in further developing the OATS since its initial installation at NREL: R. Hansen, L. Roybal, D. Myers, and K. Algra. This work was funded under the National Center for Photovoltaics at the National Renewable Energy Laboratory managed for the U. S. Department of Energy by the Midwest Research Institute under contract no. DE-AC36-83CH-10093.

\section{REFERENCES}

1. ASTM E 1596 Standard Test Methods for Solar Radiation Weathering of Photovoltaic Modules, American Society for Testing and Materials, West Conshohocken, PA, 1994.

2. ASTM E 1799 Standard Practice for Visual Inspections of Photovoltaic Modules, American Society for Testing and Materials, West Conshohocken, PA, 1996.

3. D. Myers, NREL interoffice memo, Computing UV integral dose from TUVR data, NREL, Golden, CO, February 4, 1997.

4. Reference Meteorological and Irradiance System data monitored at the National Renewable Energy laboratory Outdoor Test Facility, Internet URL: http://rmis1minavg.nrel.gov/

5. Solar Radiation Research Laboratory data monitored at the National Renewable Energy Laboratory, Internet URL: http://rredc.nrel.gov/solar/new_data/srrl/historical/data.html

6. "Solar Radiation Data Manual for Flat-Plate and Concentrating Collectors," NREL TP/463-5607, NREL, Golden, CO, 1994 